Article

\title{
A Unique TGFB1-Driven Genomic Program Links Astrocytosis, Low-Grade Inflammation and Partial Demyelination in Spinal Cord Periplaques from Progressive Multiple Sclerosis Patients
}

\author{
Serge Nataf ${ }^{1,2, *}$, Marc Barritault ${ }^{3,4}$ and Laurent Pays ${ }^{1,2}$ \\ 1 Univ Lyon, CarMeN laboratory, Inserm U1060, INRA U1397, Université Claude Bernard Lyon 1, INSA Lyon, \\ Charles Merieux Medical School, F-69600 Oullins, France; laurent.pays@univ-lyon1.fr \\ 2 Banque de Tissus et de Cellules des Hospices Civils de Lyon, Hôpital Edouard Herriot, Place d'Arsonval, \\ F-69003 Lyon, France \\ 3 Univ Lyon, Department of Cancer Cell Plasticity, Cancer Research Center of Lyon, INSERMU1052, \\ CNRS UMR5286, University Claude Bernard Lyon 1, 151 Cours Albert Thomas, 69003 Lyon, France; \\ marc.barritault@chu-lyon.fr \\ 4 Service d'Anatomie Pathologique, Hospices Civils de Lyon, Groupement Hospitalier Est, 59 boulevard Pinel, \\ 69677 Bron, France \\ * Correspondence: serge.nataf@inserm.fr; Tel.: +33-472-117-667
}

Received: 23 August 2017; Accepted: 29 September 2017; Published: 5 October 2017

\begin{abstract}
We previously reported that, in multiple sclerosis (MS) patients with a progressive form of the disease, spinal cord periplaques extend distance away from plaque borders and are characterized by the co-occurrence of partial demyelination, astrocytosis and low-grade inflammation. However, transcriptomic analyses did not allow providing a comprehensive view of molecular events in astrocytes vs. oligodendrocytes. Here, we re-assessed our transcriptomic data and performed co-expression analyses to characterize astrocyte vs. oligodendrocyte molecular signatures in periplaques. We identified an astrocytosis-related co-expression module whose central hub was the astrocyte gene $C x 43 / G J A 1$ (connexin- 43 , also named gap junction protein $\alpha-1$ ). Such a module comprised GFAP (glial fibrillary acidic protein) and a unique set of transcripts forming a TGFB/SMAD1/SMAD2 (transforming growth factor $\beta /$ SMAD family member 1/SMAD family member 2) genomic signature. Partial demyelination was characterized by a co-expression network whose central hub was the oligodendrocyte gene NDRG1 (N-myc downstream regulated 1$)$, a gene previously shown to be specifically silenced in the normal-appearing white matter (NAWM) of MS patients. Surprisingly, besides myelin genes, the NDRG1 co-expression module comprised a highly significant number of translation/elongation-related genes. To identify a putative cause of NDRG1 downregulation in periplaques, we then sought to identify the cytokine/chemokine genes whose mRNA levels inversely correlated with those of NDRG1. Following this approach, we found five candidate immune-related genes whose upregulation associated with NDRG1 downregulation: TGFB1 (transforming growth factor $\beta 1$ ), PDGFC (platelet derived growth factor C), IL17D (interleukin 17D), IL33 (interleukin 33), and IL12A (interleukin 12A). From these results, we propose that, in the spinal cord periplaques of progressive MS patients, TGFB1 may limit acute inflammation but concurrently induce astrocytosis and an alteration of the translation/elongation of myelin genes in oligodendrocytes.
\end{abstract}

Keywords: multiple sclerosis; neuroinflammation; astrocytes; myelin; bioinformatics 


\section{Introduction}

Multiple sclerosis (MS) is a neuroinflammatory disorder of the central nervous system (CNS) and the leading cause of permanent neurological disability in young adults [1]. While autoimmune mechanisms targeting the myelin sheath have been extensively demonstrated, there are still uncertainties regarding the pathophysiology of MS progressive forms [2-5]. Importantly, patients suffering from secondary or primary progressive multiple sclerosis (SPMS and PPMS, respectively) frequently exhibit slowly evolving spinal cord-related symptoms and studies based on magnetic resonance imaging (MRI) or neuropathological analyses demonstrated a high occurrence of spinal cord lesions as compared to patients with a relapsing-remitting form of the disease (RRMS) [6,7]. In this context, we recently described a particular type of tissue alteration in the spinal cord of MS patients with SPMS or PPMS [8]. We found that periplaques, i.e., areas that surround the borders of fully-demyelinated lesions, are characterized by a partial loss of myelin, a low-grade inflammatory process and an astrocytosis signed by a constant upregulation of the astrocyte markers $C \times 43 / G J A 1$ (connexin-43 also named gap junction protein $\alpha-1$ ) and $A Q P 4$ (aquaporin 4). Spinal cord periplaques extend distance away from the plaque borders and appear to evolve, at least in part, independently from plaque activity. However, when performing paired comparisons between periplaques and areas of adjacent normal-appearing white matter (NAWM), whole genome transcriptomic analyses did not allow providing a comprehensive picture of the molecular events driving astrocytosis, inflammation and partial demyelination in periplaques. Indeed, only 34 genes were found to be constantly upregulated in periplaques and 57 constantly downregulated. A potential caveat of the differential expression approach we selected concerns the varied levels of molecular alterations that may occur in areas of NAWM $[9,10]$. In particular, previous studies demonstrated that NAWM in MS brains or spinal cords exhibit: (i) signs of low-grade inflammation $[9,10]$ and astrocytosis [11-13]; (ii) an abnormal lipid and protein composition of myelin sheaths [14-16]; and (iii) an epigenetic silencing of the oligodendrocyte gene NDRG1 ( $N$-myc downstream regulated 1) [17]. Thus, when performing paired comparisons between periplaques and NAWM, the genomic alterations occurring in NAWM might have masked functionally-relevant molecular events taking place in both periplaques and NAWM.

In the present paper, we re-assessed our transcriptomic data with the aim of identifying gene co-expression networks that would link astrocytosis, inflammation and myelin alterations in spinal cord periplaques. In a first step, we identified $C \times 43 / G J A 1$ as the only astrocyte-specific hub gene among genes that constantly co-upregulated in periplaques. To identify a molecular signature of astrocytosis in periplaques, we then used Cx43/GJA1 as a "bait" and determined the top-200 genes that more closely co-upregulated with Cx43/GJA1. Interestingly, besides GFAP (glial fibrillary acidic protein), this Cx43/GJA1 genomic module comprised the two cytokines IL17D (interleukin 17D) and IL33 (interleukin 33) and a set of genes forming a TGFB/SMAD1/SMAD2 progliotic signature (transforming growth factor $\beta /$ SMAD family member 1/SMAD family member 2). In parallel, we identified NDRG1 as the only oligodendrocyte-specific hub gene among genes that constantly co-downregulated in spinal cord periplaques. To identify a molecular signature of oligodendrocytes in periplaques and NAWM, we then used NDRG1 as a "bait" and determined the top-200 genes that more closely co-downregulated with NDRG1. Interestingly, NDRG1 co-expression module comprised not only the myelin genes PLP1 (proteolipid protein 1), MBP (myelin basic protein) and MOBP (myelin-associated oligodendrocyte basic protein), but also a highly significant number of transcripts involved in the process of mRNA translation and elongation. Finally, to unravel molecular mechanisms potentially linking partial demyelination to inflammation, we established a list of 193 candidate genes coding for cytokines, chemokines or growth factors from which we identified the top five genes whose mRNA levels inversely correlated with those of NDRG1 in periplaques. We found that NDRG1 mRNA levels inversely correlated with TGFB1 (transforming growth factor $\beta$ 1), IL33 (interleukin 33), IL17D (interleukin 17D), IL12A (interleukin 12A) and PDGFC (platelet derived growth factor C). 


\section{Results}

\subsection{Workflow and Results Summary}

Our workflow and main results are summarized in Figures 1 and 2.

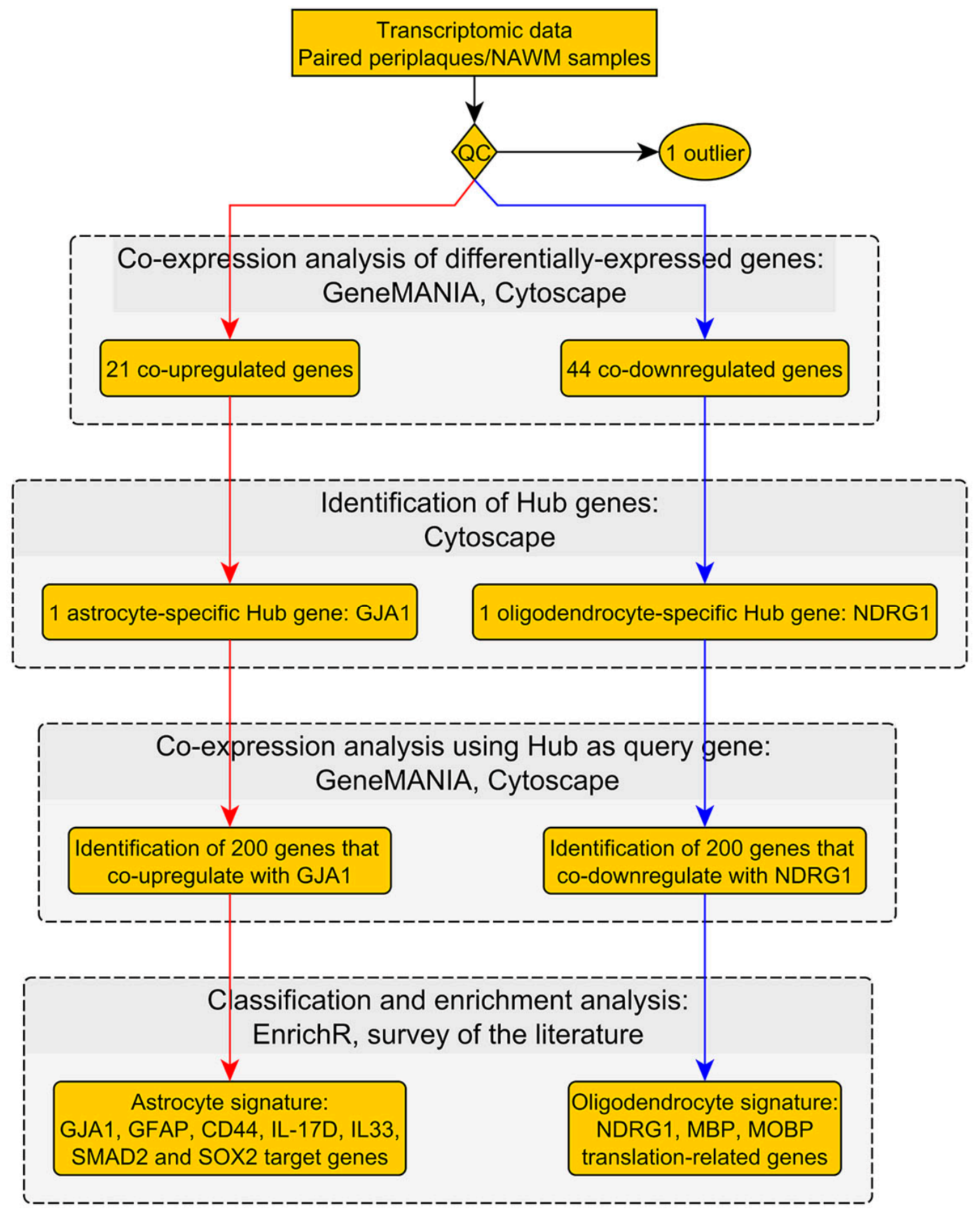

Figure 1. Workflow No. 1. 


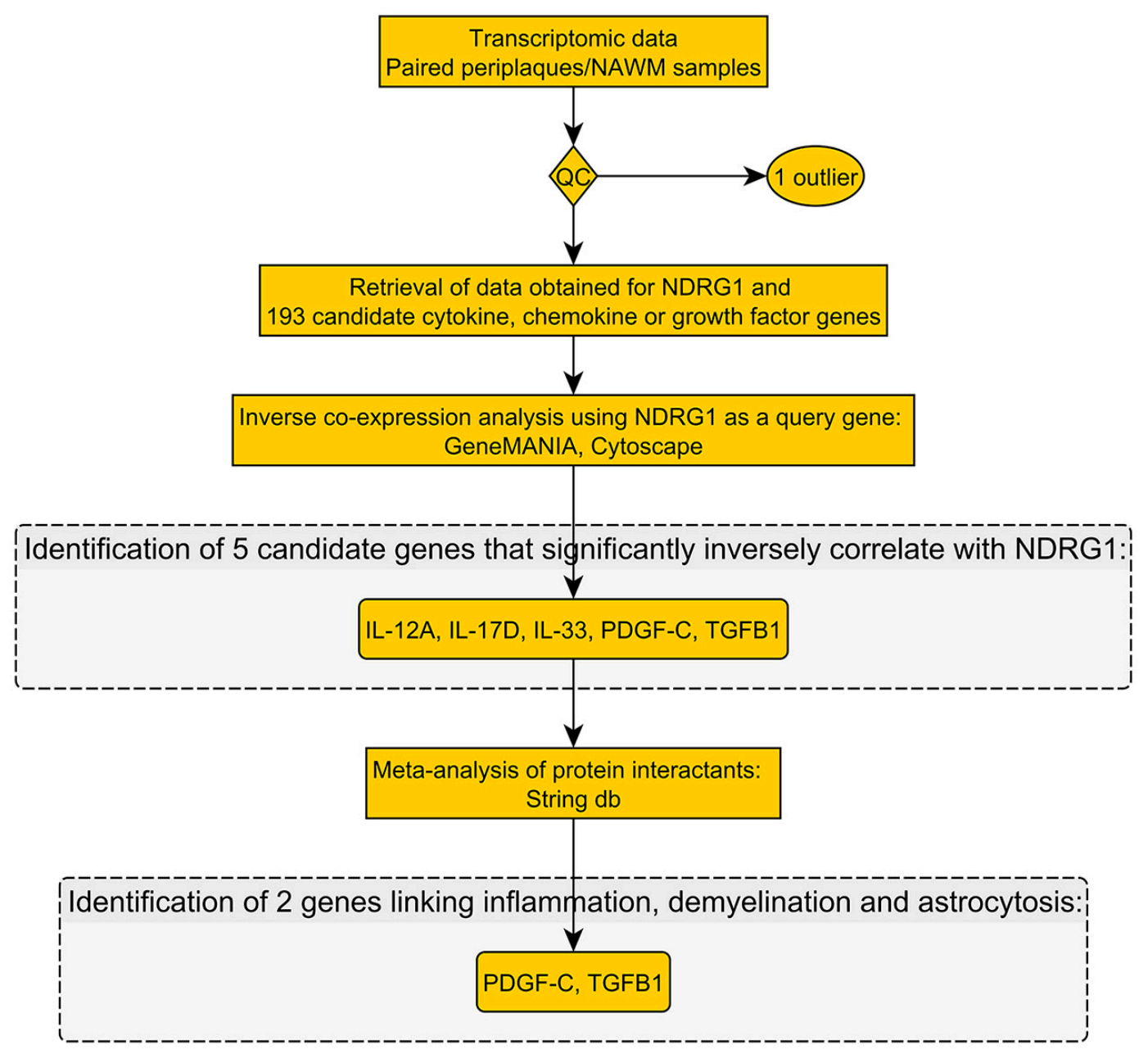

Figure 2. Workflow No. 2.

\subsection{Identification of $C x 43 / G J A 1$ as an Upregulated Astrocyte-Related Hub Gene in Spinal Cord Periplaques}

Based on the data we previously obtained by paired comparisons of periplaques vs. NAWM transcriptomic profiles, we assessed whether the 34 coding genes identified as constantly upregulated in periplaques were indeed co-upregulated in periplaques. We identified a set of 21 co-upregulated mRNA species among which Cx43/GJA1 (Gap junction protein $\alpha 1$ also named connexin 43) was the only astrocyte-related hub gene (Figure 3). Importantly, Cx43 on astrocytes was previously reported to be upregulated in the NAWM of MS patients as compared to controls [18].

\subsection{Identification of NDRG1 as a Downregulated Oligodendrocyte-Related Hub Gene in Spinal Cord Periplaques}

We then assessed whether the 57 coding genes identified as constantly downregulated in paired comparisons of periplaques vs. NAWM were co-downregulated in periplaques. We identified a set of 44 co-downregulated genes (Figure 4 and Table 1) among which NDRG1 was the only hub gene previously recognized as being specifically expressed by oligodendrocytes in the central nervous system $[17,19,20]$. 


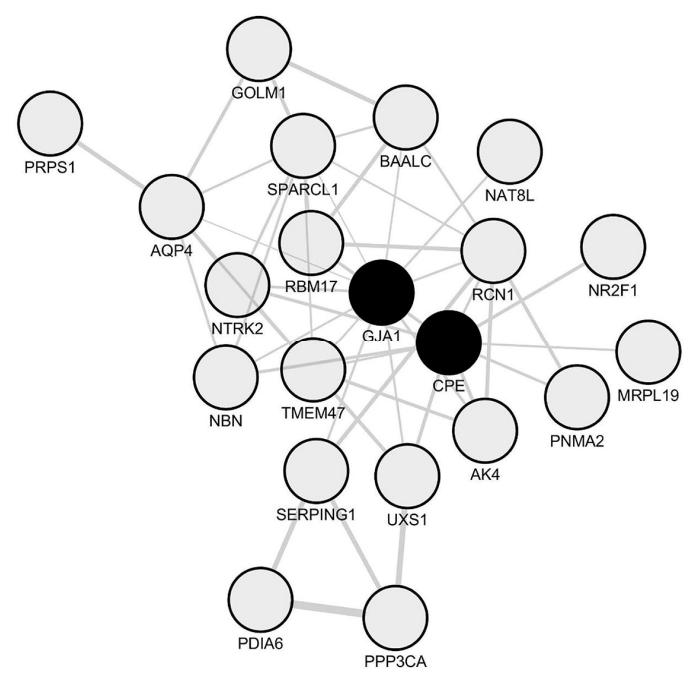

Figure 3. Network of co-upregulated genes in spinal cord periplaques. A co-expression network was generated with the set of genes that are constantly upregulated in periplaques as compared to adjacent normal-appearing white matter (NAWM). In this co-expression module, hubs were defined as genes (nodes) being connected to at least half of the total number of genes (nodes) forming the network. Two hub genes (black-filled nodes) were identified, namely CPE (Carboxypeptidase E) and the astrocyte-specific gene marker Cx43/GJA1 (gap junction protein $\alpha 1$ also named connexin 43). Genes are designated by their gene symbols.

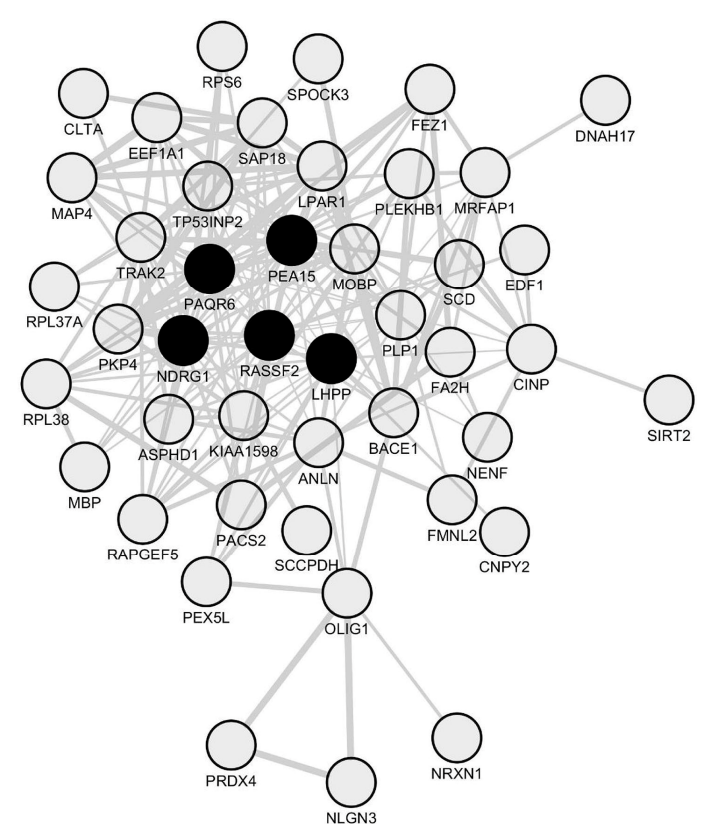

Figure 4. Network of co-downregulated genes in spinal cord periplaques. A co-expression network was generated with the set of genes that are constantly downregulated in periplaques as compared to adjacent normal-appearing white matter (NAWM). In this co-expression module, hubs were defined as genes (nodes) being connected to at least half of the total number of genes (nodes) forming the network. Five hub genes (black-filled nodes) were identified, namely NDRG1 ( $N$-myc downstream regulated 1), PEA15 (phosphoprotein enriched in astrocytes 15), RASSF2 (Ras association domain family member 2), PAQR6 (progestin and adipoQ receptor family member 6) and LHPP (phospholysine phosphohistidine inorganic pyrophosphate phosphatase). Genes are designated by their gene symbols. Full names of functionally-relevant genes are provided in Table 1. 
Table 1. Hub genes and oligodendrocyte-related genes that co-downregulate in spinal cord periplaques as compared to NAWM.

\begin{tabular}{cc}
\hline & Hub Genes \\
\hline LHPP & Phospholysine phosphohistidine inorganic pyrophosphate phosphatase \\
NDRG1 & N-myc downstream regulated 1 \\
PAQR6 & Progestin and adipoQ receptor family member VI \\
PEA15 & Phosphoprotein enriched in astrocytes 15 \\
RASSF2 & Ras association (RalGDS/AF-6) domain family member 2 \\
\hline \multicolumn{2}{c}{ Oligodendrocyte-Related Genes } \\
\hline NDRG1 & N-myc downstream regulated 1 \\
MOBP & Myelin-associated oligodendrocyte basic protein \\
MBP & Myelin basic protein \\
PLP1 & Proteolipid protein 1 \\
OLIG1 & Oligodendrocyte transcription factor 1 \\
SIRT2 & Sirtuin (silent mating type information regulation 2 homolog) 2 (Saccharomyces cerevisiae) \\
FA2H & Fatty acid 2-hydroxylase \\
\hline
\end{tabular}

A co-expression network was generated with the set of genes that constantly downregulated in periplaques as compared to adjacent NAWM. In this co-expression module, hubs were defined as genes (nodes) being connected to at least half of the total number of genes (nodes) forming the network.

\subsection{A Unique Set of Genes Co-Upregulate with CX43/GJA1 in Periplaques of MS Spinal Cords}

To identify a putative astrocyte molecular signature in periplaque areas of MS spinal cords, we used the astrocyte-specific hub gene C $x 43 / G J A 1$ as a "bait" and retrieved the top-200 mRNA species that more closely co-expressed with $C x 43 / G J A 1$ in our whole set of data. Functionally-relevant genes are shown in Table 2 and Figure 5. The full list of $C x 43 / G J A 1$ co-expressed genes is provided in Supplementary Data S1.

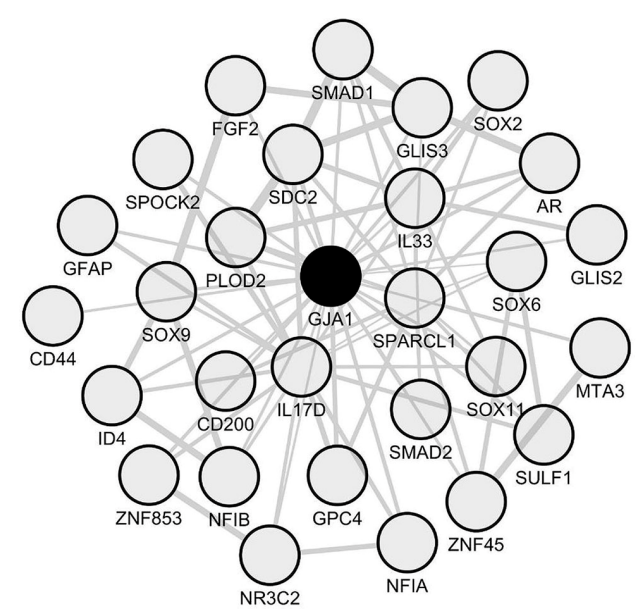

Figure 5. Astrocyte signature inferred from the GJA1/C $x 43$ co-expression module in spinal cord periplaques. To identify an astrocyte molecular signature in spinal cord periplaques, we used the astrocyte-specific hub gene $C x 43 /$ JJA1 as a "bait" and retrieved the top-200 mRNA species that most closely co-upregulated with $C x 43 /$ GJA1. The co-expression network formed by functionally-relevant genes is shown. Genes are designated by their gene symbols. Gene full names are provided in Table 2. 
Table 2. List of functionally-relevant genes that co-express with GJA1/Cx43 in spinal cord periplaque areas.

\begin{tabular}{|c|c|}
\hline & Transcription Factors \\
\hline$A R$ & Androgen receptor \\
\hline NR3C2 & Nuclear receptor subfamily 3 group C member 2 (mineralocorticoid receptor) \\
\hline SMAD1 & SMAD family member 1 \\
\hline SMAD2 & SMAD family member 2 \\
\hline SOX2 & SRY (sex determining region Y)-box 2 \\
\hline SOX6 & SRY (sex determining region Y)-box 6 \\
\hline SOX9 & SRY (sex determining region Y)-box 9 \\
\hline SOX11 & SRY (sex determining region $Y$ )-box 11 \\
\hline ZNF45 & Zinc finger protein 175 \\
\hline ZNF853 & Zinc finger protein 853 \\
\hline GLIS2 & GLIS family zinc finger 2 \\
\hline GLIS3 & GLIS family zinc finger 3 \\
\hline NFIA & Nuclear factor I/A \\
\hline NFIB & Nuclear factor I/B \\
\hline ID4 & Inhibitor of DNA binding 4, dominant negative helix-loop-helix protein \\
\hline \multirow[t]{2}{*}{ MTA3 } & Metastasis associated 1 family, member 3 \\
\hline & Cytokines \\
\hline IL33 & Interleukin 33 \\
\hline \multirow[t]{2}{*}{ IL17D } & Interleukin 17D \\
\hline & ECM-Related Genes \\
\hline SPARCL1 & SPARC-like 1 (hevin) \\
\hline SDC2 & Syndecan 2 \\
\hline PLOD2 & Procollagen-lysine, 2-oxoglutarate 5-dioxygenase 2 \\
\hline GPC4 & Glypican 4 \\
\hline SULF1 & Sulfatase 1 \\
\hline \multirow[t]{2}{*}{ SPOCK2 } & SPARC/osteonectin, cwcv and kazal-like domains proteoglycan (testican) 2 \\
\hline & Others \\
\hline GFAP & Glial fibrillary acidic protein \\
\hline$C D 44$ & CD44 molecule (Indian blood group) \\
\hline CD200 & CD200 molecule \\
\hline FGF2 & Fibroblast growth factor 2 (basic) \\
\hline
\end{tabular}

A co-expression analysis was performed in which the astrocyte-specific gene CX43/GJA1 was used as a "bait" to identify a putative molecular signature of reactive astrocytes in periplaque areas of MS spinal cords. The top-200 genes that more closely co-expressed with CX43/GJA1 were identified. Listed are genes considered as functionally-relevant in the context of astrocytosis and inflammation.

Besides GFAP, such a genomic network comprised three groups of genes that we found of particular relevance in the context of astrocytosis, inflammation and tissue remodeling: (i) transcription factors (TFs); (ii) cytokines; and (iii) genes coding for extra-cellular matrix (ECM) molecules (Figure 3 and Table 2). Interestingly, the TFs that co-expressed with $C x 43 / G J A 1$ comprised SMAD1 and SMAD2, which are two major signaling components of the TGF- $\beta$ and Bone Morphogenetic Proteins (BMPs) pro-gliotic pathways [21-24]. Moreover, TFs that co-expressed with Cx43/GJA1 also comprised SOX2 a stem cell-related gene expressed by proliferating astrocytes $[25,26]$ and NFAI, a positive regulator of GFAP transcription [27]. On the other hand, the androgen receptor $(A R)$, which was also found to co-express with $C x 43 / G J A 1$, was previously shown to inhibit reactive astrocytosis under varied CNS conditions [28-33]. Of note, $A R$ co-expressed also with $C x 43 / G J A 1$ when excluding the two male patients from our analysis (Supplementary Data S2). To establish a potential link between CX43/GJA1 co-expressed TFs and other genes of the CX43/GJA1 module, we performed an enrichment analysis using ChEA2016, a Chip-Seq and Chip-Chip database and webtool [34]. We found that the GJA1/Cx43 module was significantly enriched (adjusted $p$-value $<0.01$ ) in previously identified gene targets of AR or SOX2 in human cells (Supplementary Data S3). However, the GJA1/Cx43 module 
was not enriched in known functional pathways as assessed with the Reactome 2016 database and webtool [35]. Surprisingly, we found that only two cytokines, namely IL17D and IL33, co-upregulated with Cx43/GJA1 in spinal cord periplaque areas. Other inflammation-related genes comprised notably $C D 44$ and $C D 200$ that were both previously demonstrated on reactive astrocytes [36,37]. Finally, the GJA1/Cx43 module comprised several ECM-related genes that are expressed by reactive astrocytes: GPC4 [38], SULF1 [39] and SPARCL1 [40].

\subsection{A Unique Set of Genes Co-Express with NDRG1 in Periplaque Areas of MS Spinal Cords}

To unravel a molecular signature of oligodendrocytes in periplaque areas of MS spinal cords, we used the oligodendrocyte-related hub gene NDRG1 as a "bait" and retrieved the top-200 mRNA species that more closely co-expressed with NDRG1. The full list of NDRG1 co-expressed genes is provided in Supplementary Data S4. As expected, such a module comprised genes coding for myelin proteins, namely $M B P, M O B P$ and PLP1. Similarly to the Cx43/GJA1 module, the NDRG1 module also comprised several TFs. However, the network of NDRG1 co-expressed genes was not enriched in known targets of these TFs, as assessed with the ChEA2016 database and webtool. A survey of the "TargetScan microRNA" [41] database showed that the NDRG1 co-expression module was not significantly enriched in known targets of miRNAs. However, pathway analysis with the webtool "Reactome 2016" showed a highly significant enrichment in genes involved in the functional pathway "Eukaryotic Translation Elongation" (Reactome 2016, adjusted $p$-value $=37 \times 10^{-9}$ ) (Figure 6 and Table 3).

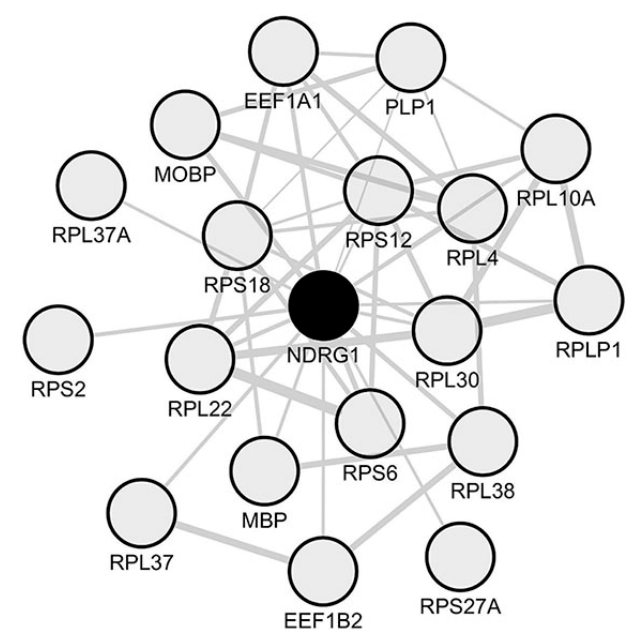

Figure 6. Oligodendrocyte signature inferred from the NDRG1 co-expression module in spinal cord periplaques. To identify an oligodendrocyte molecular signature in spinal cord periplaques, we used the oligodendrocyte-specific hub gene NDRG1 (N-myc downstream regulated 1 ) as a "bait" and retrieved the top-200 mRNA species that most closely co-downregulated with NDRG1. The co-expression network formed by functionally-relevant genes is shown. Genes are designated by their gene symbols. Gene full names are provided in Table 3. 
Table 3. List of functionally-relevant genes that co-express with NDRG1 in spinal cord periplaque areas.

\begin{tabular}{cc}
\hline & Myelin-Related Genes \\
\hline MBP & Myelin basic protein \\
POBP & Myelin-associated oligodendrocyte basic protein \\
Proteolipid protein 1
\end{tabular}

A co-expression analysis was performed in which the oligodendrocyte-specific gene NDRG1 (N-myc downstream regulated 1) was used as a "bait" to identify a putative molecular signature of oligodendrocytes in spinal cord periplaques. The top-200 genes that more closely co-express with NDRG1 in spinal cord periplaque areas were identified. Listed are genes considered as functionally-relevant in the context of myelin loss.

This finding appears of particular interest since, in oligodendrocytes, the translation of $M B P$ and $M O B P$ was previously shown to rely on specific mechanisms requiring a transport of the protein translation machinery (including ribosomal proteins) along the cell processes of oligodendrocytes [42-47]. To explore the existence of potential links between NDRG1 and the processes of translation/elongation, we performed a meta-analysis of NDRG1 protein interactants. While the STRING database allowed to recover only 20 direct protein interactants with no significant enrichment relating with translation/elongation, the Wiki-Pi database, gathering data from high throughput technologies, listed 64 NDRG1 interactants (Supplementary Data S5) that showed a highly significant enrichment in the "Translation" pathway (Reactome 2016, adjusted $p$-value $=4.80 \times 10^{-11}$ ). Similar results were obtained when assessing NDRG1 interactants in the protein interactome database TissueNet v.2 [48] (Supplementary Data S5). This result points to a potential link between NDRG1 downregulation in oligodendrocytes and a subsequent altered translation/elongation of myelin genes leading to partial demyelination.

2.6. Identification of Candidate Soluble Factors that May Trigger NDRG1 Silencing in Periplaque Areas of MS Spinal Cords

While a previous study showed that NDRG1 is specifically silenced in the NAWM of MS patients [17], we found that NDRG1 was constantly downregulated in spinal cord periplaques as compared to adjacent NAWM. We thus sought to identify candidate soluble factors (in particular immune molecules) that would be potentially involved in a repression of NDRG1 expression in periplaque areas of MS spinal cords. To this aim, we first established a list of 193 candidate genes coding for cytokines, chemokines or growth factors. We then used the GeneMANIA software to identify the top five candidate genes whose mRNA levels harbored the more closely inverse correlation with NDRG1 mRNA levels in our whole set of data. These top five genes were established as follows: IL17D, IL33, IL12A, PDGF-C and TGFB1 (Figure 7). 


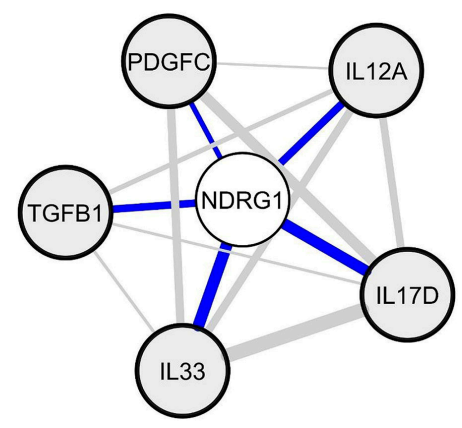

Figure 7. Identification of candidate soluble factors that putatively repress NDRG1 expression. Starting from a list of 193 candidate genes coding for cytokines, chemokines or growth factors, we used the GeneMANIA software to identify mRNA species whose levels inversely correlated with those of NDRG1 ( $N$-myc downstream regulated 1$)$ in spinal cord periplaques. The top five genes whose expression levels inversely correlated with NDRG1 were: TGFB1 (transforming growth factor $\beta$ 1), IL33 (interleukin 33), IL17D (interleukin 17D), IL12A (interleukin 12A) and PDGFC (platelet derived growth factor C).

\subsection{Assessment in Normal Human Astrocytes of Genes Associated with the Identified Cx43/GJA1 Module}

We sought to determine whether the genes forming the functional core of the Cx43/GJA1 co-expression module were also expressed in normal human astrocytes. To this aim, we assessed the human CNS RNA-Seq database published by the Ben Barres group $[49,50]$ in which mRNA levels were obtained by RNA-Seq from highly-purified CNS cell types (astrocytes, neurons, endothelial cells, and oligodendrocytes) extracted from normal human brains. Using this database, we found that, out of the 28 genes forming the functional core of the CX43/GJA1 module (depicted in Figure 5 and Table 2), 24 were significantly enriched in mature human astrocytes as compared to other mature CNS cells (Supplementary Data S6); three genes for which values were not provided could not be assessed and only one gene (SULF1) was not statistically enriched in human mature astrocytes. Then, starting from the 24 genes identified as enriched in mature human astrocytes, we set a threshold of $10 \times$ (in astrocytes as compared to other CNS cell types) to identify those which could be considered as astrocyte-specific. The list of such astrocyte-specific genes is presented in Table 4.

Table 4. List of functionally-relevant genes that co-express with $C x 43 / G L A 1$ in spinal cord periplaque areas and harbor an astrocyte-specific profile in normal mature human astrocytes.

\begin{tabular}{ccccccc}
\hline $\begin{array}{c}\text { Gene } \\
\text { Symbol }\end{array}$ & $\begin{array}{c}\text { Astrocytes } \\
\text { (Mean FPKM) }\end{array}$ & SD & $\begin{array}{c}\text { Other CNS Cells } \\
\text { (Mean FPKM) }\end{array}$ & SD & $\begin{array}{c}\text { Fold } \\
\text { Change }\end{array}$ & $p$-Value \\
\hline FGF2 & 15.9 & 4.1 & 0.9 & 0.6 & 16.9 & $5.40 \times 10^{-5}$ \\
GLIS3 & 5.5 & 1.7 & 0.3 & 0.3 & 16.1 & $5.29 \times 10^{-5}$ \\
SDC2 & 34.0 & 9.7 & 1.8 & 1.6 & 18.5 & $5.50 \times 10^{-5}$ \\
IL33 & 17.4 & 10.4 & 0.4 & 0.5 & 46.1 & $5.04 \times 10^{-5}$ \\
GFAP & 119.7 & 113.1 & 8.5 & 11.9 & 14.2 & $5.91 \times 10^{-5}$ \\
SOX9 & 50.5 & 18.6 & 2.2 & 1.9 & 22.7 & $5.52 \times 10^{-5}$ \\
SPARCL1 & 1913.8 & 576.8 & 104.0 & 137.6 & 18.4 & $1.47 \times 10^{-5}$ \\
IL17D & 21.7 & 4.8 & 1.9 & 1.7 & 11.2 & $5.52 \times 10^{-5}$ \\
ID4 & 22.5 & 7.8 & 0.4 & 0.4 & 51.3 & $5.20 \times 10^{-5}$ \\
GPC4 & 3.5 & 1.0 & 0.2 & 0.2 & 17.4 & $4.25 \times 10^{-5}$ \\
\hline
\end{tabular}

The human CNS RNA-Seq database published by the Ben Barres group [49,50] was used to determine the level of astrocyte specificity in functionally-relevant genes that co-expressed with $C x 43 / G J A 1$ in spinal cord periplaques. Measures in other CNS cells include pooled results obtained by RNA-Seq on human neurons, endothelial cells, oligodendrocytes and microglia. Statistical comparisons were performed with a Mann-Whitney test. SD: standard deviation; FKPM: fragments per kilobase of exon per million fragments. 
Since, based on this approach, IL17D and IL33 could be considered as astrocyte-specific in normal human mature astrocytes, we then aimed at determining whether other interleukins could be identified as being astrocyte-specific as well. Interestingly, when assessing the Ben Barres database and using again the threshold of X10 (in astrocytes as compared to other CNS cell types), we found that, out of 33 interleukins tested, only IL17D and IL33 could be considered as astrocyte-specific (Table 5 and Supplementary Data S7). In addition, among the 33 interleukins tested, we found that: (i) the highest mRNA levels as expressed in FKPM (fragments per kilobase of exon per million fragments mapped) were observed for IL17D and ILL33; and (ii) only seven interleukins could be considered as constitutively expressed when using the threshold of 0.5 FKPM (the threshold used in the Ben Barres database to determine whether or not a gene can be considered as being expressed). Finally, it is worth noting that studies from the Ben Barres group showed that the astrocyte specificity of IL17D is not observed in mice [51] meaning that functions exerted by IL17D in the human brain may not be extrapolated from studies performed in mice.

Table 5. List of interleukins that are constitutively expressed by normal mature human astrocytes.

\begin{tabular}{ccccccc}
\hline $\begin{array}{c}\text { Gene } \\
\text { Symbol }\end{array}$ & $\begin{array}{c}\text { Astrocytes } \\
\text { (Mean FPKM) }\end{array}$ & SD & $\begin{array}{c}\text { Other CNS Cells } \\
\text { (Mean FPKM) }\end{array}$ & SD & $\begin{array}{c}\text { Fold } \\
\text { Change }\end{array}$ & $p$-Value \\
\hline IL17D & 21.7 & 4.8 & 1.9 & 1.7 & 11.2 & $5.52 \times 10^{-5}$ \\
IL33 & 17.4 & 10.4 & 0.4 & 0.5 & 46.1 & $5.04 \times 10^{-5}$ \\
IL1B & 7.0 & 5.9 & 219.4 & 344.3 & 0.0 & 0.002 \\
IL6 & 2.1 & 3.1 & 8.2 & 9.6 & 0.3 & 0.095 \\
IL9 & 0.7 & 0.7 & 0.2 & 0.1 & 4.3 & 0.0049 \\
IL18 & 0.7 & 0.6 & 14.1 & 20.1 & 0.0 & 0.01 \\
IL1A & 0.6 & 0.4 & 28.9 & 49.9 & 0.0 & 0.01 \\
\hline
\end{tabular}

The human CNS RNA-Seq database published by the Ben Barres group [49,50] was used to determine the constitutive expression and level of astrocyte specificity in 33 human interleukins. Measures in other CNS cells include pooled results obtained by RNA-seq on human neurons, endothelial cells, oligodendrocytes and microglia. Statistical comparisons were performed with a Mann-Whitney test. SD: standard deviation; FKPM: fragments per kilobase of exon per million fragments.

\subsection{Assessment in Normal Human Oligodendrocytes of Genes Associated with the Identified NDRG1 Module}

We sought to determine whether the genes forming the functional core of the NDRG1 co-expression module we identified were also expressed in human normal oligodendrocytes. Using the human CNS RNA-Seq database in Section 2.6, we found that, out of the 18 genes forming this functional core, 16 were statistically enriched in oligodendrocytes as compared to other CNS cells (Supplementary Data S8). Interestingly, several translation/elongation-related genes from this core module were enriched by a factor of 2-3 in oligodendrocytes as compared to other CNS cells: RPS12 (Ribosomal protein S12), RPL37A (Ribosomal protein L37a), RPS18 (Ribosomal protein S18), RPL30 (Ribosomal protein L30), RPL22 (Ribosomal protein L22), RPS6 (Ribosomal protein S6), RPL38 (Ribosomal protein L38), RPL37 (Ribosomal protein L38) and EEF1B2 (Eukaryotic translation elongation factor $1 \beta 2$ ) (Supplementary Data S8).

\subsection{Identification of a Molecular Pathway Linking MYCN ((MYCN proto-oncogene, bHLH transcription factor) to PDGFC and TGFB1}

NDRG1 was originally identified as a major target gene repressed by the transcription factor MYCN (also named $N$-Myc) in neuroblastoma cells [52,53]. Since then, in multiple cell types, MYCN was shown to silence NDRG1 gene expression via a process involving a hypermethylation of the NDRG1 promoter [52-57]. On this basis, we performed a meta-analysis of the human interactome to determine whether signaling pathways could link MYCN to the identified candidate molecules (i.e., IL17D, IL33, IL12A, PDGF-C and TGFB1). We found that PDFGRA (platelet derived growth factor receptor $\alpha$, a PDGFC receptor) and TGFBR1 (transforming growth factor $\beta$ receptor 1, a TGFB1 receptor) are second shell interactants of MAX (Myc associated factor X) and SP1 (Sp1 transcription 
factor) (Figure 8), two TFs that are recruited by MYCN during the transcriptional repression of specific target genes [54]. No direct or secondary interactions could be retrieved between MYCN and the receptors for IL33 or IL12A (the IL17D receptor being not yet identified could not be investigated).

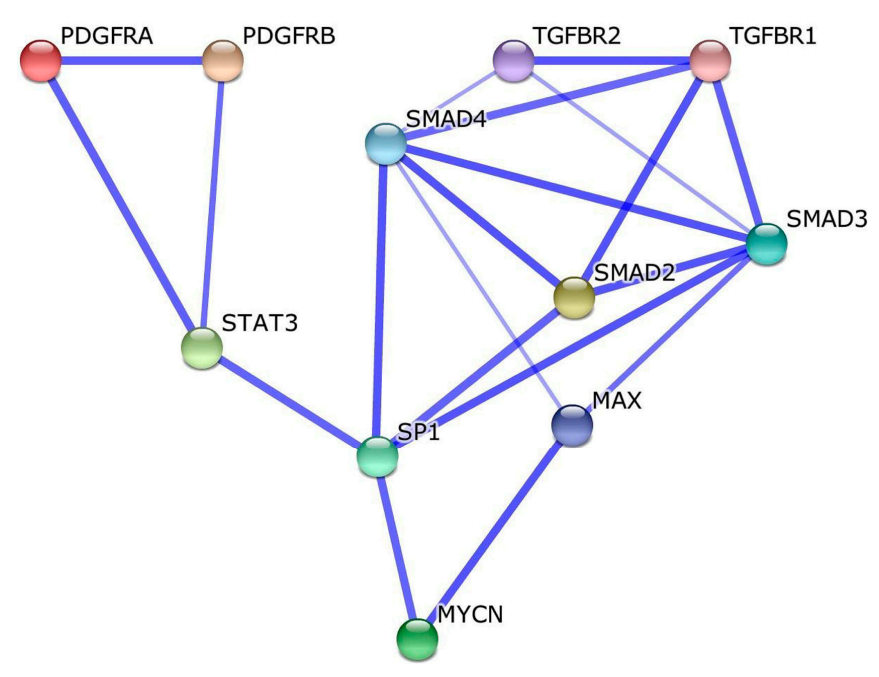

Figure 8. Identification of molecular pathways linking PDGFC (platelet derived growth factor C) and TGFB1 (transforming growth factor $\beta$ 1) to MYCN (MYCN proto-oncogene, bHLH transcription factor). A meta-analysis of the human interactome was performed to determine whether signaling pathways could link MYCN (a known repressor of NDRG1 expression) to the identified candidate IL17D, IL33, IL12A, PDGFC and TGFB1. Data show that PDGFRA (platelet derived growth factor receptor $\alpha$, a PDGFC receptor) and TGFBR1 (transforming growth factor $\beta$ receptor 1 , a TGFB1 receptor) are second shell interactants of MAX (Myc associated factor X) and SP1 (Sp1 transcription factor), two transcription factors that are recruited by MYCN during the transcriptional repression of specific target genes.

\section{Discussion}

In this paper, gene co-expression analyses were performed in order to infer astrocytes vs. oligodendrocytes molecular signatures in spinal cord periplaques of MS patients. Regarding astrocytes, genes that were found to co-upregulate with GJA1/Cx43 in periplaques formed a pro-gliotic signature which composition is compatible with a combined TGFB/SAMD1/SMAD2- and SOX2-driven program. While TGFB and SOX2 were both previously identified as astrocytosis-promoting factors [21-24], TGFB was further shown to induce an astrocyte-specific developmental program that, in turn, prevents effective remyelination in MS plaques and periplaques [58]. Superimposing the TGFB/SMAD1/SMAD2 and SOX2 progliotic signatures, we also found that the GJA1/Cx43 module was characterized by a highly significant enrichment in genes that are regulated by the AR. Interestingly, even when excluding males from our study, the $A R$ was still co-expressed with $G J A 1 / C x 43$. As androgens are known to prevent astrocytosis [28-33], our results raise the possibility that in males and females suffering from progressive forms of MS, activation of the AR is somehow defective and fails to downregulate a large set of progliotic genes induced by the TGFB/SMAD1/SMAD2 pathway. This could be due to an age-related decrease of circulating testosterone or of the circulating androgen precursors (Dehydroepiandrosterone and Androstendiol) that can be intracellularly metabolized into testosterone [59-62]. Another explanation, not exclusive from the former one, could be that the AR signaling pathway might be hampered or disrupted in periplaque astrocytes despite a normal level of circulating or intracrine testosterone. Supporting this view, mechanisms of mutual exclusion between AR and TGFB signaling pathways were previously demonstrated in different cell types [63-68].

With regard to inflammation, we found that, in spinal cord periplaques, the astrocytois signature formed by GJA1/Cx43 gene module comprised only two cytokines: IL17D and IL33. These two 
cytokines were previously shown to be not only highly expressed in normal (quiescent) human mature astrocytes but also to be astrocyte-specific at least to some extent $[49,50]$. Deciphering the specific roles exerted by such cytokines in MS pathophysiology would deserve specific experimental approaches that would possibly need the use of human cells. Indeed, while IL17D is a pro-inflammatory cytokine directing the intra-tissular recruitment of NK T-cells in mice [69,70] (via a yet unknown receptor), its abundant expression in quiescent astrocytes appears to be specific to the human species [51]. It is worth noting that IL17D was proposed to share with other members of the IL17 family, a specific ability to induce TGFB secretion in a large range of cell types [71,72]. Interestingly also, the astrocytic expression of IL33 was recently demonstrated in MS plaques and IL33 was shown to inhibit the de novo myelination of rat axons in vitro [73]. Nevertheless, other works reported that IL33 promotes remyelination [74] and exerts potent anti-inflammatory and neuroprotective functions [75]. Again, discrepancies between results could possibly be explained by species-specific differences, notably regarding the expression profile of IL1RL1 (also named ST2), the receptor to IL33 [76,77]. In particular, when comparing the constitutive expression of IL1RL1 in murine vs. human CNS cells, IL1RL1 is exclusively expressed by endothelial cells in human cells while its expression is limited to macrophages/microglia in murine cells. Along this line, the pleiotropic effects of IL33 on immune cells were shown to be regulated by a finely-tuned and cell-specific expression of IL1RL1, notably on T-cells [76,77]. Finally, besides TFs and immune genes, the GJA1/C $x 43$ module included several key extra-cellular matrix (ECM)-related genes involved in tissue remodeling. Among these, Procollagen Lysyl Hydroxylase 2 (PLOD2) is a TGFB-induced enzyme [78-80] that promotes fibrosis via the crosslinking of collagen molecules [81-83].

The second aim of our work was to identify a molecular signature of oligodendrocytes in the spinal cord periplaques of MS patients. Among the network of genes that were constantly downregulated in periplaques, NDRG1 was identified as the only oligodendrocyte-specific hub gene. Such a finding has to be interpreted in light of a recent work demonstrating that NDRG1 is also the only oligodendrocyte-specific gene whose silencing was demonstrated in the NAWM of MS patients. These data, while further supporting the role of NDRG1 as a master regulator of oligodendrocyte differentiation and myelin maintenance $[17,19,20]$, suggest also that NDRG1 may be a major target of a yet uncharacterized process leading to diffuse myelin alterations in periplaques. When using NDRG1 as a bait gene to identify a large co-expression module in oligodendrocytes, we found that only three genes coding for myelin proteins co-downregulated with NDRG1 in periplaques: $M B P$, $M O B P$ and PLP1. Interestingly, as opposed to the GJA1/Cx43 module, no specific enrichment in known targets of co-expressed TF could be evidenced in the NDRG1 module. Moreover, we were neither able to identify enrichment in apoptosis-related pathways nor in miRNA targets, which would have provided molecular schemes explaining oligodendrocyte cell loss or altered myelin gene expression. In contrast, the NDRG1 co-expression module was highly significantly enriched in genes involved in translation/elongation of mRNAs. Although, at this stage, one may only extrapolate on the significance of such an enrichment, it is important to underscore that the translation of both $M B P$ and $M O B P$ mRNAs in oligodendrocytes rely on a unique mechanism during which various components of the protein translation machinery (including ribosomal proteins) are transported along the cell processes of oligodendrocytes [42-47]. Strikingly, when performing a meta-analysis of human NDRG1 protein interactants, we found a highly significant enrichment in proteins involved in the "Translation" pathway (Reactome 2016, adjusted $p$-value $=1.80 \times 10^{-11}$ ) (Supplementary Data S5). On this basis, one may thus propose that NDRG1 silencing in oligodendrocytes may hamper myelination via the coordinated downregulation of a specific subset of ribosomal genes supporting the translation/elongation of $M B P$ and MOBP mRNAs.

Finally, we attempted to identify candidate soluble molecules that could be responsible for NDRG1 downregulation in spinal cord periplaques. Our analysis pointed to a network of five genes whose expression levels inversely correlated with those of NDRG1 with the highest levels of confidence: (i) IL17D and IL33, the two cytokines found to co-upregulate with GJA1/Cx43 in periplaques; (ii) IL12-A, 
a potent inducer of TH1 (T-Helper 1) polarization [84]; (iii) PDGFC (Platelet-derived growth factor C), a profibrotic gene [85,86] and a regulator of the neurovascular unit [87]; and (iv) TGFB1 (Transforming growth factor-1). In fact, these correlations do not allow establishing a functional causative link between an upregulation of these cytokines and the downregulation of NDRG1 expression. Again, we used bioinformatics tools to explore such putative links and performed a meta-analysis of the protein interactants potentially linking the identified candidate cytokines with $\mathrm{N}$-Myc. Indeed, a well identified mechanism of NDRG1 repression relies on the binding of $N$-Myc to the promoter region of NDRG1 and the subsequent recruitment of histone deacetylases leading to promoter hypermethylation and an epigenetic silencing of NDRG1 [52-57]. Our meta-analysis showed that only TGFBR1 (an oligodendrocyte-expressed receptor to TGFB1) and PDGRA (an oligodendrocyte-expressed receptor to PDGFC) formed a close (second shell) protein network with N-MyC. Overall, since the NDRG1 promoter was shown to be hypermethylated in the NAWM of MS patients [17], our results indicate that TGFB1 and/or PDGFC released in MS periplaques could be responsible for a silencing of NDRG1 in periplaques and, to a lesser extent, in the NAWM.

Overall, our work points to a major role of TGFB1 in the development of astrocytosis and diffuse myelin alterations in the spinal cord periplaques of MS patients. In particular, we propose a new pathophysiological scheme where TGF- $\beta 1$ would be central to a self-perpetuated process during which: (i) IL17-D, synthesized by reactive astrocytes, triggers the production of TGFB1; and (ii) astrocyte-derived TGFB1 fuels chronic gliosis and hamper myelination via a transcriptional repression of NDRG1. Thus, blocking TGFB1 could possibly reverse the TGFB1-induced downregulation of NDRG1 in oligodendrocytes, allowing a physiological level of translation/elongation of myelin genes to be achieved in oligodendrocytes. Supporting the hypothesis of a reversible dysfunction of oligodendrocyte in progressive MS, recent studies showed that biotin, an activator of myelin synthesis, exerted therapeutic effects on progressive MS patients when administered at high doses $[88,89]$. While further studies are needed to test the role of TGFB1 in MS pathophysiology, it is important to notice that the monoclonal antibody Fresolimumab directed against all TGFB isoforms is available for clinical trials [90], cross the blood-brain barrier [91] and is currently under evaluation in patients suffering from systemic sclerosis [92]. Finally, one may keep in mind that, although TGFB1 is generally considered as an overall anti-inflammatory cytokine, robust in vivo data previously showed that overexpression of TGFB1 in the CNS aggravates experimental autoimmune encephalitis [93,94].

\section{Materials and Methods}

\subsection{Transcriptomic Data}

Co-expression networks were generated from a previously published set of transcriptomic data that our group obtained by whole genome analyses of paired NAWM and periplaque samples derived from 8 SPMS patients [8]. Data are available at the public gene array repository bank GEO DataSets (Ref: GSE52139). To ensure the highest level of confidence to co-expression analyses, we first submitted transcriptomic data to a stringent quality control using the arrayQualityMetrics Bioconductor package (v3.28.2) [95] in R (v3.3.0). We removed from further analyses the transcriptomic profile obtained from 1 out of 16 samples as it was detected as an outlier by both boxplots and MA plots criteria.

\subsection{Generation of a Global Co-Expression Network}

An expression file was generated that comprised an "OBJECT" column in which gene symbols were provided for each row and 15 "SAMPLE" columns compiling normalized data values for each sample and each transcript. This expression file was then imported in the GeneMANIA Cytoscape plugin (version 3.3.4 data version 2014-08-02-core) $[96,97]$ allowing the generation of a co-expression network that, based on the Pearson correlation test, gathered 735,240 interactions. 


\subsection{Connectivity Analysis of Gene Co-Expression Networks}

Starting from the global co-expression network generated from periplaque and NAWM samples, we investigated the correlation links that could be established between genes that were previously found to be differentially regulated in paired comparisons between periplaques and NAWM samples. Using the GeneMANIA plugin in Cytoscape software, 2 sets of genes were entered separately as independent queries: (i) the 34 genes found to be constantly upregulated in periplaques [8]; and (ii) the 57 genes found to be constantly downregulated in periplaques [8]. For each analysis, the number of additional connected genes to be identified was set to zero in order to limit the search for co-expression links to query genes only. Then, to identify hub genes among these modules, we used the "Network analysis" tool in Cytoscape software. A hub gene was defined as a gene (node) being connected to at least half of the total number of genes (nodes) forming the network.

\subsection{Identification and Analysis of the Cx43/GJA1 Co-Upregulated Gene Network}

Starting from the global expression network loaded on Cytoscape/GeneMANIA, CX43/GJA1 (GJA1) was entered as a query gene, and the number of connected genes to be identified was set to 200. The generated list was then assessed with regard to the presence of genes considered as functionally relevant in the context of astrocytosis, inflammation and tissue remodeling. These notably included genes coding for: (i) cytokines; (ii) extracellular matrix (ECM); or (iii) transcription factors (TF). Identification of functionally-relevant genes was performed by a survey of the literature, on the basis of GO terms annotation, and using the TF database "AnimalTFDB" [98]. Finally, the 200 genes forming the $C \times 43 / G J A 1$ co-expression network were also analyzed with regard to their enrichment in: (i) genes involved in specific pathways; (ii) genes identified as known targets of human transcription factors (TF); and (iii) genes identified as known targets of miRNA. These enrichment analyses were performed using the EnrichR webtools [99]: "ChEA2016" [34] (allowing to survey a total of 622 ChIP-ChIP or ChIP-seq sets of data that were manually curated), "TargetScan microRNA" [41] and "Reactome 2016" [35].

\subsection{Identification and Analysis of the NDRG1 Co-Downregulated Gene Network}

Starting from the global expression network loaded on Cytoscape/GeneMANIA, NDRG1 was entered as a query gene, and the number of connected genes to be identified was set to 200 . The generated list was then assessed with regard to the presence of genes coding for myelin or oligodendrocyte-related molecules as determined by GO terms annotation and a survey of the literature. The complete list of genes forming the NDRG1 co-expression network was also analyzed with regard to its enrichment in: (i) genes involved in specific pathways; (ii) genes identified as known targets of human transcription factors (TF); and (iii) genes identified as known targets of miRNA. These enrichment analyses were performed using the open source website EnrichR [99] and the same webtools as described above.

\subsection{Identification of aNetwork of NDRG1 Inversely Correlated Genes Coding for Cytokines/Chemokines or Growth Factors}

As GeneMANIA recognizes only positive correlation links, its use for the identification of mRNA species that inversely correlate with a given query gene requires the prior replacement of the corresponding mRNA values by opposite values. To identify a network of cytokines, chemokines or growth factors that inversely correlated with NDRG1, we first established a list of 193 candidate genes (Supplementary Data S9) that included notably 38 interleukins, 17 interferons, 36 chemokines, 35 growth factors, 22 metalloproteases, 6 angiogenic factors and 5 granzymes. GeneMANIA was then loaded with an expression file that comprised: (i) the original values obtained for each of the probes corresponding to the above-described list of cytokines/chemokines or growth factors; and (ii) the values opposite to the original ones obtained with the NDRG1 probe. Again, the number of additional 
connected genes to be identified was set to zero. NDRG1 was entered as a query gene, and the number of connected genes to be identified was set to 10. As GeneMANIA was conceived to process large sets of data, its algorithms include a sparsification process during which only the 50 strongest correlation links for each object are retained [96]. Therefore, for expression files comprising a low number of objects, correlation links being ranked in the top 50 might still not reach significance. To circumvent this possible drawback, for each of the 10 genes that were initially identified as inversely correlated with NDRG1 with the GeneMANIA software, the statistical significance of the inverse correlation was checked using the Pearson correlation test. Only genes for which $p$ values were $\leq 0.01$ were taken into account.

\subsection{Meta-Analysis of MYCN Protein Interactants}

When needed, the open source websites "STRING" [100] and Wiki-Pi [101] were used to perform meta-analyses of protein-protein interactions. STRING allows protein interaction networks to be generated via a survey of distinct databases that list known protein interactions from published and manually-curated biochemical studies [100]. Here, we used STRING to identify interactants that would link MYCN to the receptors IL12RB1, IL12RB2, IL1RL1 (IL33 receptor), PDGFRA, PDGFRB (platelet derived growth factor receptor $\beta$, a PDGFC receptor), TGFBR1, TGFBR2 (transforming growth factor $\beta$ receptor 2, a TGFB1 receptor) and TGFBR3 (transforming growth factor $\beta$ receptor 3 , a TGFB1 receptor). Several round of analyses were performed in which two query proteins were entered for each analysis: MYCN and one of the above-mentioned receptors. The number of first-shell protein interactants to be identified was set to 500 and only high confidence interactions (score $\geq 0.7$ according to the classification provided by the STRING website) retrieved from published and manually-curated biochemical studies were taken into account. Selected interaction networks were then loaded in Cytoscape in order to facilitate the visualization of identified pathways. In another set of analyses, we used the Wiki-Pi database to retrieve NDRG1 protein interactants. Wiki-Pi is a resource that is not manually-curated but allows a large survey of both Biogrid [102] and HPRD [103] databases obtained by high throughput technologies. Wiki-Pi compiles 48419 unique binary biophysical interactions among 10,492 human proteins.

Supplementary Materials: Supplementary materials can be found at www.mdpi.com/1422-0067/18/10/2097/s1.

Acknowledgments: The authors would like to thank Odile Damour, Céline Auxenfans and Pascale Pascal from the "Bank of Cells and Tissues" of the Hospices Civils de Lyon for their help in the development of a bioinformatics facility. The authors also thank Marine Guillen for her technical help on bioinformatics analyses. No specific funding was obtained to perform bioinformatics analyses and to cover the publication costs.

Author Contributions: Serge Nataf, Marc Barritault and Laurent Pays performed the bioinformatics analyses. Serge Nataf wrote the paper.

Conflicts of Interest: The authors declare no conflict of interest.

\section{Abbreviations}

$\begin{array}{ll}\text { MS } & \text { Multiple sclerosis } \\ \text { RRMS } & \text { Relapsing-remitting multiple sclerosis } \\ \text { SPMS } & \text { Secondary progressive multiple sclerosis } \\ \text { PPMS } & \text { Primary progressive multiple sclerosis } \\ \text { NAWM } & \text { Normal-appearing white matter }\end{array}$

\section{References}

1. Compston, A.; Coles, A. Multiple sclerosis. Lancet 2002, 359, 1221-1231. [CrossRef]

2. Antel, J.; Antel, S.; Caramanos, Z.; Arnold, D.L.; Kuhlmann, T. Primary progressive multiple sclerosis: Part of the MS disease spectrum or separate disease entity? Acta. Neuropathol. 2012, 123, 627-638. [CrossRef] [PubMed] 
3. Ciccarelli, O.; Barkhof, F.; Bodini, B.; de Stefano, N.; Golay, X.; Nicolay, K.; Pelletier, D.; Pouwels, P.J.W.; Smith, S.A.; et al. Pathogenesis of multiple sclerosis: Insights from molecular and metabolic imaging. Lancet Neurol. 2014, 13, 807-822. [CrossRef]

4. Larochelle, C.; Uphaus, T.; Prat, A.; Zipp, F. Secondary progression in multiple sclerosis: Neuronal exhaustion or distinct pathology? Trends Neurosci. 2016, 39, 325-339. [CrossRef] [PubMed]

5. Lassmann, H.; van Horssen, J.; Mahad, D. Progressive multiple sclerosis: Pathology and pathogenesis. Nat. Rev. Neurol. 2012, 8, 647-656. [CrossRef] [PubMed]

6. Kearney, H.; Miller, D.H.; Ciccarelli, O. Spinal cord MRI in multiple sclerosis-Diagnostic, prognostic and clinical value. Nat. Rev. Neurol. 2015, 11, 327-338. [CrossRef] [PubMed]

7. Kearney, H.; Altmann, D.R.; Samson, R.S.; Yiannakas, M.C.; Wheeler-Kingshott, C.A.M.; Ciccarelli, O.; Miller, D.H. Cervical cord lesion load is associated with disability independently from atrophy in MS. Neurology 2015, 84, 367-373. [CrossRef] [PubMed]

8. Lieury, A.; Chanal, M.; Androdias, G.; Reynolds, R.; Cavagna, S.; Giraudon, P.; Confavreux, C.; Nataf, S. Tissue remodeling in periplaque regions of multiple sclerosis spinal cord lesions. Glia 2014, 62, 1645-1658. [CrossRef] [PubMed]

9. Zeis, T.; Graumann, U.; Reynolds, R.; Schaeren-Wiemers, N. Normal-appearing white matter in multiple sclerosis is in a subtle balance between inflammation and neuroprotection. Brain 2007, 131, 288-303. [CrossRef] [PubMed]

10. Melief, J.; de Wit, S.J.; van Eden, C.G.; Teunissen, C.; Hamann, J.; Uitdehaag, B.M.; Swaab, D.; Huitinga, I. HPA axis activity in multiple sclerosis correlates with disease severity, lesion type and gene expression in normal-appearing white matter. Acta Neuropathol. 2013, 126, 237-249. [CrossRef] [PubMed]

11. Sinclair, C.; Mirakhur, M.; Kirk, J.; Farrell, M.; McQuaid, S. Up-regulation of osteopontin and alphaBeta-crystallin in the normal-appearing white matter of multiple sclerosis: An immunohistochemical study utilizing tissue microarrays. Neuropathol. Appl. Neurobiol. 2005, 31, 292-303. [CrossRef] [PubMed]

12. Seewann, A.; Vrenken, H.; van der Valk, P.; Blezer, E.L.A.; Knol, D.L.; Castelijns, J.A.; Polman, C.H.; Pouwels, P.J.W.; Barkhof, F.; Geurts, J.J.G. Diffusely abnormal white matter in chronic multiple sclerosis: Imaging and histopathologic analysis. Arch. Neurol. 2009, 66, 601-609. [CrossRef] [PubMed]

13. Mellergård, J.; Tisell, A.; Dahlqvist Leinhard, O.; Blystad, I.; Landtblom, A.-M.; Blennow, K.; Olsson, B.; Dahle, C.; Ernerudh, J.; Lundberg, P.; et al. Association between change in normal appearing white matter metabolites and intrathecal inflammation in natalizumab-treated multiple sclerosis. PLoS ONE 2012, 7, e44739. [CrossRef] [PubMed]

14. Trotter, J.L.; Wegescheide, C.L.; Garvey, W.F.; Tourtellotte, W.W. Studies of myelin proteins in multiple sclerosis brain tissue. Neurochem. Res. 1984, 9, 147-152. [CrossRef] [PubMed]

15. Johnson, D.; Sato, S.; Quarles, R.H.; Inuzuka, T.; Brady, R.O.; Tourtellotte, W.W. Quantitation of the myelin-associated glycoprotein in human nervous tissue from controls and multiple sclerosis patients. J. Neurochem. 1986, 46, 1086-1093. [CrossRef] [PubMed]

16. Wheeler, D.; Bandaru, V.V.R.; Calabresi, P.A.; Nath, A.; Haughey, N.J. A defect of sphingolipid metabolism modifies the properties of normal appearing white matter in multiple sclerosis. Brain 2008, 131, 3092-3102. [CrossRef] [PubMed]

17. Huynh, J.L.; Garg, P.; Thin, T.H.; Yoo, S.; Dutta, R.; Trapp, B.D.; Haroutunian, V.; Zhu, J.; Donovan, M.J.; Sharp, A.J.; et al. Epigenome-wide differences in pathology-free regions of multiple sclerosis-affected brains. Nat. Neurosci. 2014, 17, 121-130. [CrossRef] [PubMed]

18. Markoullis, K.; Sargiannidou, I.; Schiza, N.; Hadjisavvas, A.; Roncaroli, F.; Reynolds, R.; Kleopa, K.A. Gap junction pathology in multiple sclerosis lesions and normal-appearing white matter. Acta Neuropathol. 2012, 123, 873-886. [CrossRef] [PubMed]

19. Echaniz-Laguna, A.; Degos, B.; Bonnet, C.; Latour, P.; Hamadouche, T.; Lévy, N.; Leheup, B. NDRG1-linked Charcot-Marie-Tooth disease (CMT4D) with central nervous system involvement. Neuromuscul. Disord. 2007, 17, 163-168. [CrossRef] [PubMed]

20. Pietiainen, V.; Vassilev, B.; Blom, T.; Wang, W.; Nelson, J.; Bittman, R.; Back, N.; Zelcer, N.; Ikonen, E. NDRG1 functions in LDL receptor trafficking by regulating endosomal recycling and degradation. J. Cell Sci. 2013, 126, 3961-3971. [CrossRef] [PubMed] 
21. Luo, J.; Lin, A.H.; Masliah, E.; Wyss-Coray, T. Bioluminescence imaging of Smad signaling in living mice shows correlation with excitotoxic neurodegeneration. Proc. Natl. Acad. Sci. USA 2006, 103, 18326-18331. [CrossRef] [PubMed]

22. Schachtrup, C.; Ryu, J.K.; Helmrick, M.J.; Vagena, E.; Galanakis, D.K.; Degen, J.L.; Margolis, R.U.; Akassoglou, K. Fibrinogen triggers astrocyte scar formation by promoting the availability of active TGFafter vascular damage. J. Neurosci. 2010, 30, 5843-5854. [CrossRef] [PubMed]

23. Gomes, W.A.; Mehler, M.F.; Kessler, J.A. Transgenic overexpression of BMP4 increases astroglial and decreases oligodendroglial lineage commitment. Dev. Biol. 2003, 255, 164-177. [CrossRef]

24. Fuller, M.L.; DeChant, A.K.; Rothstein, B.; Caprariello, A.; Wang, R.; Hall, A.K.; Miller, R.H. Bone morphogenetic proteins promote gliosis in demyelinating spinal cord lesions. Ann. Neurol. 2007, 62, 288-300. [CrossRef] [PubMed]

25. Wanner, I.B.; Anderson, M.A.; Song, B.; Levine, J.; Fernandez, A.; Gray-Thompson, Z.; Ao, Y.; Sofroniew, M.V. Glial scar borders are formed by newly proliferated, elongated astrocytes that interact to corral inflammatory and fibrotic cells via STAT3-dependent mechanisms after spinal cord injury. J. Neurosci. 2013, 33, 12870-12886. [CrossRef] [PubMed]

26. Robel, S.; Berninger, B.; Götz, M. The stem cell potential of glia: Lessons from reactive gliosis. Nat. Rev. Neurosci. 2011, 12, 88-104. [CrossRef] [PubMed]

27. Brun, M.; Coles, J.E.; Monckton, E.A.; Glubrecht, D.D.; Bisgrove, D.; Godbout, R. Nuclear factor I regulates brain fatty acid-binding protein and glial fibrillary acidic protein gene expression in malignant glioma cell lines. J. Mol. Biol. 2009, 391, 282-300. [CrossRef] [PubMed]

28. Hussain, R.; Ghoumari, A.M.; Bielecki, B.; Steibel, J.; Boehm, N.; Liere, P.; Macklin, W.B.; Kumar, N.; Habert, R.; Mhaouty-Kodja, S.; et al. The neural androgen receptor: A therapeutic target for myelin repair in chronic demyelination. Brain 2013, 136, 132-146. [CrossRef] [PubMed]

29. Acaz-Fonseca, E.; Avila-Rodriguez, M.; Garcia-Segura, L.M.; Barreto, G.E. Regulation of astroglia by gonadal steroid hormones under physiological and pathological conditions. Prog. Neurobiol. 2016, 144, 5-26. [CrossRef] [PubMed]

30. Coers, S.; Tanzer, L.; Jones, K.J. Testosterone treatment attenuates the effects of facial nerve transection on glial fibrillary acidic protein (GFAP) levels in the hamster facial motor nucleus. Metab. Brain Dis. 2002, 17, 55-63. [CrossRef] [PubMed]

31. Barreto, G.; Veiga, S.; Azcoitia, I.; Garcia-Segura, L.M.; Garcia-Ovejero, D. Testosterone decreases reactive astroglia and reactive microglia after brain injury in male rats: Role of its metabolites, oestradiol and dihydrotestosterone. Eur. J. Neurosci. 2007, 25, 3039-3046. [CrossRef] [PubMed]

32. Arevalo, M.A.; Santos-Galindo, M.; Acaz-Fonseca, E.; Azcoitia, I.; Garcia-Segura, L.M. Gonadal hormones and the control of reactive gliosis. Horm. Behav. 2013, 63, 216-221. [CrossRef] [PubMed]

33. Giatti, S.; Rigolio, R.; Romano, S.; Mitro, N.; Viviani, B.; Cavaletti, G.; Caruso, D.; Garcia-Segura, L.M.; Melcangi, R.C. Dihydrotestosterone as a protective agent in chronic experimental autoimmune encephalomyelitis. Neuroendocrinology 2015, 101, 296-308. [CrossRef] [PubMed]

34. Lachmann, A.; Xu, H.; Krishnan, J.; Berger, S.I.; Mazloom, A.R.; Ma'ayan, A. ChEA: Transcription factor regulation inferred from integrating genome-wide ChIP-X experiments. Bioinformatics 2010, 26, 2438-2444. [CrossRef] [PubMed]

35. Fabregat, A.; Sidiropoulos, K.; Garapati, P.; Gillespie, M.; Hausmann, K.; Haw, R.; Jassal, B.; Jupe, S.; Korninger, F.; McKay, S.; et al. The reactome pathway knowledgebase. Nucleic Acids Res. 2016, 44, D481-D487. [CrossRef] [PubMed]

36. Koning, N.; Swaab, D.F.; Hoek, R.M.; Huitinga, I. Distribution of the immune inhibitory molecules CD200 and CD200R in the normal central nervous system and multiple sclerosis lesions suggests neuron-glia and glia-glia interactions. J. Neuropathol. Exp. Neurol. 2009, 68, 159-167. [CrossRef] [PubMed]

37. Gabel, S.; Koncina, E.; Dorban, G.; Heurtaux, T.; Birck, C.; Glaab, E.; Michelucci, A.; Heuschling, P.; Grandbarbe, L. Inflammation promotes a conversion of astrocytes into neural progenitor cells via NF- $\mathrm{kB}$ activation. Mol. Neurobiol. 2016, 53, 5041-5055. [CrossRef] [PubMed]

38. Allen, N.J.; Bennett, M.L.; Foo, L.C.; Wang, G.X.; Chakraborty, C.; Smith, S.J.; Barres, B.A. Astrocyte glypicans 4 and 6 promote formation of excitatory synapses via GluA1 AMPA receptors. Nature 2012, 486, 410-414. [CrossRef] [PubMed] 
39. Higginson, J.R.; Thompson, S.M.; Santos-Silva, A.; Guimond, S.E.; Turnbull, J.E.; Barnett, S.C. Differential sulfation remodelling of heparan sulfate by extracellular 6-O-sulfatases regulates fibroblast growth factor-induced boundary formation by glial cells: Implications for glial cell transplantation. J. Neurosci. 2012, 32, 15902-15912. [CrossRef] [PubMed]

40. Lively, S.; Moxon-Emre, I.; Schlichter, L.C. SC1/hevin and reactive gliosis after transient ischemic stroke in young and aged rats. J. Neuropathol. Exp. Neurol. 2011, 70, 913-929. [CrossRef] [PubMed]

41. Agarwal, V.; Bell, G.W.; Nam, J.-W.; Bartel, D.P. Predicting effective microRNA target sites in mammalian mRNAs. Elife 2015, 4. [CrossRef] [PubMed]

42. Gould, R.M.; Freund, C.M.; Barbarese, E. Myelin-associated oligodendrocytic basic protein mRNAs reside at different subcellular locations. J. Neurochem. 1999, 73, 1913-1924. [PubMed]

43. Torvund-Jensen, J.; Steengaard, J.; Reimer, L.; Fihl, L.B.; Laursen, L.S. Transport and translation of MBP mRNA is regulated differently by distinct hnRNP proteins. J. Cell Sci. 2014, 127, 1550-1564. [CrossRef] [PubMed]

44. Müller, C.; Bauer, N.M.; Schäfer, I.; White, R. Making myelin basic protein-from mRNA transport to localized translation. Front. Cell. Neurosci. 2013, 7, 169. [CrossRef] [PubMed]

45. Seiberlich, V.; Bauer, N.G.; Schwarz, L.; Ffrench-Constant, C.; Goldbaum, O.; Richter-Landsberg, C. Downregulation of the microtubule associated protein Tau impairs process outgrowth and myelin basic protein mRNA transport in oligodendrocytes. Glia 2015, 63, 1621-1635. [CrossRef] [PubMed]

46. Colman, D.R.; Kreibich, G.; Frey, A. B.; Sabatini, D.D. Synthesis and incorporation of myelin polypeptides into CNS myelin. J. Cell Biol. 1982, 95, 598-608. [CrossRef] [PubMed]

47. Gould, R.M.; Freund, C.M.; Palmer, F.; Feinstein, D.L. Messenger RNAs located in myelin sheath assembly sites. J. Neurochem. 2000, 75, 1834-1844. [CrossRef] [PubMed]

48. Basha, O.; Barshir, R.; Sharon, M.; Lerman, E.; Kirson, B.F.; Hekselman, I.; Yeger-Lotem, E. The TissueNet v.2 database: A quantitative view of protein-protein interactions across human tissues. Nucleic Acids Res. 2017, 45, D427-D431. [CrossRef] [PubMed]

49. Zhang, Y.; Sloan, S.A.; Clarke, L.E.; Caneda, C.; Plaza, C.A.; Blumenthal, P.D.; Vogel, H.; Steinberg, G.K.; Edwards, M.S.B.; Li, G.; et al. Purification and characterization of progenitor and mature human astrocytes reveals transcriptional and functional differences with mouse. Neuron 2016, 89, 37-53. [CrossRef] [PubMed]

50. Zhang, Y.; Chen, K.; Sloan, S.A.; Bennett, M.L.; Scholze, A.R.; O'Keeffe, S.; Phatnani, H.P.; Guarnieri, P.; Caneda, C.; Ruderisch, N.; et al. An RNA-sequencing transcriptome and splicing database of glia, neurons, and vascular cells of the cerebral cortex. J. Neurosci. 2014, 34, 11929-11947. [CrossRef] [PubMed]

51. Zhang, Y.; Sloan, S.; Barres, B.A. Purification of functional human astrocytes. U.S. Patent Application No. 15/158,404, 24 November 2016.

52. Li, J.; Kretzner, L. The growth-inhibitory NDRG1 gene is a Myc negative target in human neuroblastomas and other cell types with overexpressed N- or C-myc. Mol. Cell. Biochem. 2003, 250, 91-105. [CrossRef] [PubMed]

53. Shimono, A.; Okuda, T.; Kondoh, H. N-myc-dependent repression of ndr1, a gene identified by direct subtraction of whole mouse embryo cDNAs between wild type and N-myc mutant. Mech. Dev. 1999, 83, 39-52. [CrossRef]

54. Gherardi, S.; Valli, E.; Erriquez, D.; Perini, G. MYCN-mediated transcriptional repression in neuroblastoma: The other side of the coin. Front. Oncol. 2013, 3, 42. [CrossRef] [PubMed]

55. Zhang, J.; Chen, S.; Zhang, W.; Zhang, J.; Liu, X.; Shi, H.; Che, H.; Wang, W.; Li, F.; Yao, L. Human differentiation-related gene NDRG1 is a Myc downstream-regulated gene that is repressed by Myc on the core promoter region. Gene 2008, 417, 5-12. [CrossRef] [PubMed]

56. Ellen, T.P.; Ke, Q.; Zhang, P.; Costa, M. NDRG1, a growth and cancer related gene: Regulation of gene expression and function in normal and disease states. Carcinogenesis 2008, 29, 2-8. [CrossRef] [PubMed]

57. Ambrosio, S.; Amente, S.; Saccà, C.D.; Capasso, M.; Calogero, R.A.; Lania, L.; Majello, B. LSD1 mediates MYCN control of epithelial-mesenchymal transition through silencing of metastatic suppressor NDRG1 gene. Oncotarget 2017, 8, 3854-3869. [CrossRef] [PubMed]

58. John, G.R.; Shankar, S.L.; Shafit-Zagardo, B.; Massimi, A.; Lee, S.C.; Raine, C.S.; Brosnan, C.F. Multiple sclerosis: Re-expression of a developmental pathway that restricts oligodendrocyte maturation. Nat. Med. 2002, 8, 1115-1121. [CrossRef] [PubMed] 
59. Zwain, I.H.; Yen, S.S.C. Neurosteroidogenesis in astrocytes, oligodendrocytes, and neurons of cerebral cortex of rat brain. Endocrinology 1999, 140, 3843-3852. [CrossRef] [PubMed]

60. Allolio, B.; Arlt, W. DHEA treatment: Myth or reality? Trends Endocrinol. Metab. 2002, 13, 288-294. [CrossRef]

61. Luu-The, V.; Labrie, F. The Intracrine Sex Steroid Biosynthesis Pathways. In Progress in Brain Research; 2010; Volume 181, pp. 177-192.

62. Bauman, D.R.; Steckelbroeck, S.; Penning, T.M. The roles of aldo-keto reductases in steroid hormone action. Drug News Perspect. 2004, 17, 563-578. [CrossRef] [PubMed]

63. Kang, H.-Y.; Huang, K.-E.; Chang, S.Y.; Ma, W.-L.; Lin, W.-J.; Chang, C. Differential modulation of androgen receptor-mediated transactivation by Smad3 and tumor suppressor Smad4. J. Biol. Chem. 2002, 277, 43749-43756. [CrossRef] [PubMed]

64. Chipuk, J.E.; Cornelius, S.C.; Pultz, N.J.; Jorgensen, J.S.; Bonham, M.J.; Kim, S.-J.; Danielpour, D. The androgen receptor represses transforming growth factor- signaling through interaction with Smad3. J. Biol. Chem. 2002, 277, 1240-1248. [CrossRef] [PubMed]

65. Hayes, S.A.; Zarnegar, M.; Sharma, M.; Yang, F.; Peehl, D.M.; ten Dijke, P.; Sun, Z. SMAD3 represses androgen receptor-mediated transcription. Cancer Res. 2001, 61, 2112-2118. [PubMed]

66. Wang, H.; Song, K.; Sponseller, T.L.; Danielpour, D. Novel function of androgen receptor-associated protein 55/Hic-5 as a negative regulator of Smad3 signaling. J. Biol. Chem. 2005, 280, 5154-5162. [CrossRef] [PubMed]

67. Van der Poel, H.G. Androgen receptor and TGFbeta1/Smad signaling are mutually inhibitory in prostate cancer. Eur. Urol. 2005, 48, 1051-1058. [CrossRef] [PubMed]

68. Song, K.; Wang, H.; Krebs, T.L.; Wang, B.; Kelley, T.J.; Danielpour, D. DHT selectively reverses Smad3-mediated/TGF- $\beta$-induced responses through transcriptional down-regulation of Smad3 in prostate epithelial cells. Mol. Endocrinol. 2010, 24, 2019-2029. [CrossRef] [PubMed]

69. Saddawi-Konefka, R.; Seelige, R.; Gross, E.T.E.; Levy, E.; Searles, S.C.; Washington, A.; Santosa, E.K.; Liu, B.; O'Sullivan, T.E.; Harismendy, O.; et al. Nrf2 Induces IL-17D to mediate tumor and virus surveillance. Cell Rep. 2016, 16, 2348-2358. [CrossRef] [PubMed]

70. Seelige, R.; Washington, A.; Bui, J.D. The ancient cytokine IL-17D is regulated by Nrf2 and mediates tumor and virus surveillance. Cytokine 2017, 91, 10-12. [CrossRef] [PubMed]

71. Broxmeyer, H.E.; Starnes, T.; Ramsey, H.; Cooper, S.; Dahl, R.; Williamson, E.; Hromas, R. The IL-17 cytokine family members are inhibitors of human hematopoietic progenitor proliferation. Blood 2006, 108, 770. [CrossRef] [PubMed]

72. Starnes, T.; Broxmeyer, H.E.; Robertson, M.J.; Hromas, R. Cutting edge: IL-17D, a novel member of the IL-17 family, stimulates cytokine production and inhibits hemopoiesis. J. Immunol. 2002, 169, 642-646. [CrossRef] [PubMed]

73. Allan, D.; Fairlie-Clarke, K.J.; Elliott, C.; Schuh, C.; Barnett, S.C.; Lassmann, H.; Linnington, C.; Jiang, H.-R. Role of IL-33 and ST2 signalling pathway in multiple sclerosis: Expression by oligodendrocytes and inhibition of myelination in central nervous system. Acta Neuropathol. Commun. 2016, 4, 75. [CrossRef] [PubMed]

74. Natarajan, C.; Yao, S.-Y.; Sriram, S. TLR3 agonist poly-IC induces IL-33 and promotes myelin repair. PLoS ONE 2016, 11, e0152163. [CrossRef] [PubMed]

75. Gadani, S.P.; Smirnov, I.; Smith, A.T.; Overall, C.C.; Kipnis, J. Characterization of meningeal type 2 innate lymphocytes and their response to CNS injury. J. Exp. Med. 2016, 214, jem.20161982. [CrossRef] [PubMed]

76. Molofsky, A.B.; Savage, A.K.; Locksley, R.M. Interleukin-33 in tissue homeostasis, injury, and inflammation. Immunity 2015, 42, 1005-1019. [CrossRef] [PubMed]

77. Griesenauer, B.; Paczesny, S. The ST2/IL-33 axis in immune cells during inflammatory diseases. Front. Immunol. 2017, 8, 475. [CrossRef] [PubMed]

78. Gjaltema, R.A.F.; de Rond, S.; Rots, M.G.; Bank, R.A. Procollagen lysyl hydroxylase 2 expression is regulated by an alternative downstream transforming growth factor $\beta-1$ activation mechanism. J. Biol. Chem. 2015, 290, 28465-28476. [CrossRef] [PubMed]

79. Remst, D.F.G.; Blom, A.B.; Vitters, E.L.; Bank, R.A.; van den Berg, W.B.; Blaney Davidson, E.N.; van der Kraan, P.M. Gene expression analysis of murine and human osteoarthritis synovium reveals elevation of transforming growth factor $\beta$-responsive genes in osteoarthritis-related fibrosis. Arthritis Rheumatol. 2014, 66, 647-656. [CrossRef] [PubMed] 
80. Remst, D.F.G.; Blaney Davidson, E.N.; Vitters, E.L.; Bank, R.A.; van den Berg, W.B.; van der Kraan, P.M. TGF- $\beta$ induces Lysyl hydroxylase $2 b$ in human synovial osteoarthritic fibroblasts through ALK5 signaling. Cell Tissue Res. 2014, 355, 163-171. [CrossRef] [PubMed]

81. Van der Slot, A.J.; Zuurmond, A.-M.; Bardoel, A.F.J.; Wijmenga, C.; Pruijs, H.E.H.; Sillence, D.O.; Brinckmann, J.; Abraham, D.J.; Black, C.M.; Verzijl, N.; et al. Identification of PLOD2 as telopeptide Lysyl hydroxylase, an important enzyme in fibrosis. J. Biol. Chem. 2003, 278, 40967-40972. [CrossRef] [PubMed]

82. Wu, J.; Reinhardt, D.P.; Batmunkh, C.; Lindenmaier, W.; Far, R.K.-K.; Notbohm, H.; Hunzelmann, N.; Brinckmann, J. Functional diversity of lysyl hydroxylase 2 in collagen synthesis of human dermal fibroblasts. Exp. Cell Res. 2006, 312, 3485-3494. [CrossRef] [PubMed]

83. Chen, Y.; Terajima, M.; Yang, Y.; Sun, L.; Ahn, Y.-H.; Pankova, D.; Puperi, D.S.; Watanabe, T.; Kim, M.P.; Blackmon, S.H.; et al. Lysyl hydroxylase 2 induces a collagen cross-link switch in tumor stroma. J. Clin. Investig. 2015, 125, 1147-1162. [CrossRef] [PubMed]

84. Trinchieri, G. Interleukin-12 and the regulation of innate resistance and adaptive immunity. Nat. Rev. Immunol. 2003, 3, 133-146. [CrossRef] [PubMed]

85. Campbell, J.S.; Hughes, S.D.; Gilbertson, D.G.; Palmer, T.E.; Holdren, M.S.; Haran, A.C.; Odell, M.M.; Bauer, R. L.; Ren, H.-P.; Haugen, H.S.; et al. Platelet-derived growth factor C induces liver fibrosis, steatosis, and hepatocellular carcinoma. Proc. Natl. Acad. Sci. USA 2005, 102, 3389-3394. [CrossRef] [PubMed]

86. Martin, I.V.; Borkham-Kamphorst, E.; Zok, S.; van Roeyen, C.R.C.; Eriksson, U.; Boor, P.; Hittatiya, K.; Fischer, H.-P.; Wasmuth, H.E.; Weiskirchen, R.; et al. Platelet-derived growth factor (PDGF)-C neutralization reveals differential roles of PDGF receptors in liver and kidney fibrosis. Am. J. Pathol. 2013, 182, 107-117. [CrossRef] [PubMed]

87. Lee, C.; Zhang, F.; Tang, Z.; Liu, Y.; Li, X. PDGF-C: A new performer in the neurovascular interplay. Trends Mol. Med. 2013, 19, 474-486. [CrossRef] [PubMed]

88. Sedel, F.; Bernard, D.; Mock, D.M.; Tourbah, A. Targeting demyelination and virtual hypoxia with high-dose biotin as a treatment for progressive multiple sclerosis. Neuropharmacology 2016, 110, 644-653. [CrossRef] [PubMed]

89. Sedel, F.; Papeix, C.; Bellanger, A.; Touitou, V.; Lebrun-Frenay, C.; Galanaud, D.; Gout, O.; Lyon-Caen, O.; Tourbah, A. High doses of biotin in chronic progressive multiple sclerosis: A pilot study. Mult. Scler. Relat. Disord. 2015, 4, 159-169. [CrossRef] [PubMed]

90. De Gramont, A.; Faivre, S.; Raymond, E. Novel TGF- $\beta$ inhibitors ready for prime time in onco-immunology. Oncoimmunology 2017, 6, e1257453. [CrossRef] [PubMed]

91. Den Hollander, M.W.; Bensch, F.; Glaudemans, A.W.J.M.; Oude Munnink, T.H.; Enting, R.H.; den Dunnen, W.F.A.; Heesters, M.A.A.M.; Kruyt, F.A.E.; Lub-de Hooge, M.N.; Cees de Groot, J.; et al. TGFantibody uptake in recurrent high-grade glioma imaged with 89Zr-fresolimumab PET. J. Nucl. Med. 2015, 56, 1310-1314. [CrossRef] [PubMed]

92. Rice, L.M.; Padilla, C.M.; McLaughlin, S.R.; Mathes, A.; Ziemek, J.; Goummih, S.; Nakerakanti, S.; York, M.; Farina, G.; Whitfield, M.L.; et al. Fresolimumab treatment decreases biomarkers and improves clinical symptoms in systemic sclerosis patients. J. Clin. Investig. 2015, 125, 2795-2807. [CrossRef] [PubMed]

93. Wyss-Coray, T.; Borrow, P.; Brooker, M.J.; Mucke, L. Astroglial overproduction of TGF-beta 1 enhances inflammatory central nervous system disease in transgenic mice. J. Neuroimmunol. 1997, 77, 45-50. [CrossRef]

94. Luo, J.; Ho, P.P.; Buckwalter, M.S.; Hsu, T.; Lee, L.Y.; Zhang, H.; Kim, D.-K.; Kim, S.-J.; Gambhir, S.S.; Steinman, L.; et al. Glia-dependent TGF- $\beta$ signaling, acting independently of the TH17 pathway, is critical for initiation of murine autoimmune encephalomyelitis. J. Clin. Investig. 2007, 117, 3306-3315. [CrossRef] [PubMed]

95. Huber, W.; Carey, V.J.; Gentleman, R.; Anders, S.; Carlson, M.; Carvalho, B.S.; Bravo, H.C.; Davis, S.; Gatto, L.; Girke, T.; et al. Orchestrating high-throughput genomic analysis with Bioconductor. Nat. Methods 2015, 12, 115-121. [CrossRef] [PubMed]

96. Warde-Farley, D.; Donaldson, S.L.; Comes, O.; Zuberi, K.; Badrawi, R.; Chao, P.; Franz, M.; Grouios, C.; Kazi, F.; Lopes, C.T.; et al. The GeneMANIA prediction server: Biological network integration for gene prioritization and predicting gene function. Nucleic Acids Res. 2010, 38, W214-W220. [CrossRef] [PubMed] 
97. Montojo, J.; Zuberi, K.; Rodriguez, H.; Kazi, F.; Wright, G.; Donaldson, S.L.; Morris, Q.; Bader, G.D. GeneMANIA Cytoscape plugin: Fast gene function predictions on the desktop. Bioinformatics 2010, 26, 2927-2928. [CrossRef] [PubMed]

98. Zhang, H.-M.; Liu, T.; Liu, C.-J.; Song, S.; Zhang, X.; Liu, W.; Jia, H.; Xue, Y.; Guo, A.-Y. AnimalTFDB 2.0: A resource for expression, prediction and functional study of animal transcription factors. Nucleic Acids Res. 2015, 43, D76-D81. [CrossRef] [PubMed]

99. Kuleshov, M.V.; Jones, M.R.; Rouillard, A.D.; Fernandez, N.F.; Duan, Q.; Wang, Z.; Koplev, S.; Jenkins, S. L.; Jagodnik, K.M.; Lachmann, A.; et al. Enrichr: A comprehensive gene set enrichment analysis web server 2016 update. Nucleic Acids Res. 2016, 44, W90-W97. [CrossRef] [PubMed]

100. Szklarczyk, D.; Franceschini, A.; Wyder, S.; Forslund, K.; Heller, D.; Huerta-Cepas, J.; Simonovic, M.; Roth, A.; Santos, A.; Tsafou, K.P.; et al. STRING v10: Protein-protein interaction networks, integrated over the tree of life. Nucleic Acids Res. 2015, 43, D447-D452. [CrossRef] [PubMed]

101. Orii, N.; Ganapathiraju, M.K. Wiki-Pi: A web-server of annotated human protein-protein interactions to aid in discovery of protein function. PLoS ONE 2012, 7, e49029. [CrossRef] [PubMed]

102. Chatr-aryamontri, A.; Oughtred, R.; Boucher, L.; Rust, J.; Chang, C.; Kolas, N.K.; O’Donnell, L.; Oster, S.; Theesfeld, C.; Sellam, A.; et al. The BioGRID interaction database: 2017 update. Nucleic Acids Res. 2017, 45, D369-D379. [CrossRef] [PubMed]

103. Keshava Prasad, T.S.; Goel, R.; Kandasamy, K.; Keerthikumar, S.; Kumar, S.; Mathivanan, S.; Telikicherla, D.; Raju, R.; Shafreen, B.; Venugopal, A.; et al. Human protein reference database-2009 supdate. Nucleic Acids Res. 2009, 37, D767-D772. [CrossRef] [PubMed]

(C) 2017 by the authors. Licensee MDPI, Basel, Switzerland. This article is an open access article distributed under the terms and conditions of the Creative Commons Attribution (CC BY) license (http://creativecommons.org/licenses/by/4.0/). 